\title{
Interpersonal competences of students, their interpersonal relations, and emotional intelligence
}

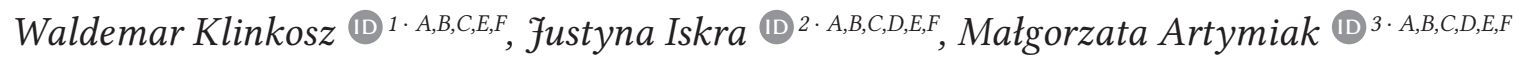 \\ 1: Institute of Psychology, Cardinal Stefan Wyszynski University, Warsaw, Poland \\ 2: Institute of Psychology, The John Paul II Catholic University of Lublin, Lublin, Poland \\ 3: University of Economics and Innovation, Lublin, Poland
}

\section{BACKGROUND}

Some of the most important interpersonal competences are: effectiveness in dealing with specific interpersonal challenges and the ability to undertake appropriate actions in a given situation; the range of interpersonal challenges with which one can effectively deal; and satisfaction derived from one's interpersonal contacts and relations, and from one's social standing. One's time at university is one of the most influential educational stages in one's life and is a time of accumulation of changes related to a variety of dimensions of life. At university, young people, often away from their parents, learn how to be independent, make new friends, and make decisions related to their personal and professional lives.

\section{PARTICIPANTS AND PROCEDURE}

The participants in the study were 173 (92 women and 81 men) psychology students of three universities in Poland who volunteered to complete three questionnaires: the Interpersonal Competence Questionnaire, the Interpersonal Adjective Scales, and the Popular Emotional Intelligence Questionnaire.

\section{RESULTS}

The results showed a positive correlation between the students' interpersonal competence and emotional intel- ligence. The research has confirmed the value of the applied methods and the significance of social competences in the development of positive interpersonal relations and the ability to adapt to a new environment.

\section{CONCLUSIONS}

The study confirmed that the interpersonal relations of initiating relationships, negative assertion, self-disclosure, providing emotional support, and conflict resolution positively correlate with the interpersonal relations directed towards cooperation, support, taking initiative, and mutual understanding and that they are also positively interdependent with emotional intelligence of the studied group. One can hope that the confirmed correlations of the students' interpersonal competences and the kinds of interpersonal connections they establish and emotional intelligence will encourage their social development and future professional activity.

\section{KEY WORDS}

students' interpersonal competences; students' interpersonal relationship; students' emotional intelligence

Corresponding Author - Waldemar Klinkosz, Ph.D., Institute of Psychology, Cardinal Stefan Wyszynski University, 1/3 Wóycickiego Str., 01-938 Warsaw, Poland, e-mail: w.klinkosz@uksw.edu.pl

AUthors' CONTRIBUtion - A: Study design - B: Data collection - C: Statistical analysis - D: Data interpretation .

E: Manuscript preparation · F: Literature search · G: Funds collection

TO CITE THIS ARTICLE - Klinkosz, W., Iskra, J., \& Artymiak, M. (2021). Interpersonal competences of students, their

interpersonal relations, and emotional intelligence. Current Issues in Personality Psychology, 9(2), 125-134.

RECEIVED 01.02.2020 • REVIEWED 21.09.2020 • ACCEPTED 25.03.2021 · PUBLISHED 03.05.2021 


\section{BACKGROUND}

\section{INTERPERSONAL SKILLS}

Interpersonal behaviour is the basis of human social activity. Nobody lives in a vacuum. It is a natural human tendency to initiate, create, and develop interpersonal relations, which form the basis of social bonds. Interpersonal relations fulfil the need for belonging, closeness, and communication with others; they are also derived from the survival instinct (McConnell, 2018; Klinkosz et al., 2017). Establishing close relations and development of interpersonal relationships form the purpose of human life. Interpersonal behaviours stem from the social character of human life. They are initiated by other people, but they are also directed towards others. They define interpersonal relations, which can be roughly divided into positives, e.g. helping others, and negative, e.g. aggression (Cabero-Almenara \& Marín-Díaz, 2018). We take part in relationships with the persons closest to us from the moment we are born. Our first relationships become prototypes of our later interpersonal relations (Sękowski \& Klinkosz, 2016).

Interpersonal competences are those which we use in relations with other people. They are helpful in achieving interpersonal successes as well as in personal and professional development. They are tied to those personal traits that influence efficient management of one's self, effective functioning in interpersonal relations, and achieving goals. They enable contact and development of ties with people in a variety of social situations that humans find themselves in (Guzmán-Simón et al., 2017; Klinkosz et al., 2017).

Interpersonal competences are essential in many professions. Teachers, social workers, healthcare workers, psychologists and others who enter into interactions with clients, families, and other specialists, ought to respect others, be inquisitive, compassionate, see things from the other person's perspective, show empathy and realistic confidence. Some of the most important interpersonal competences are: effectiveness in dealing with specific interpersonal challenges and the ability to undertake appropriate actions in a given situation; the range of interpersonal challenges which one can effectively deal with; satisfaction derived from one's interpersonal contacts and relations, and from one's social standing (McConnell, 2018; Smółka, 2016).

Interpersonal competences are key to human development. The importance of interaction with others begins in the early years, starting with the members of one's family and continuing with friends and teachers at school, to be followed later by colleagues at work. Such competences make up a significant part of relationships with other individuals and society. They are acquired, shaped, and refined through learning. Their development depends on numerous factors, such as innate predispositions, ways of learning, upbringing, and steering as well as one's one activity. An exceptionally important source of development of interpersonal competences is social training, which people are subject to throughout their whole lives, and which can take the shape of a variety of social experiences (relations with family, contacts within society, at the workplace, amongst the same age group) (DeLamater \& Ward, 2014). Interpersonal competences force one to open up and may develop inside a variety of close relationships, such as love or friendship, but also in contact with a doctor, a psychologist, a teacher, or a peer. The basis for building interpersonal competences is the ability to open up and trust others (Britton et al., 2017; Fought \& Misawa, 2016; Han \& Son, 2020; Matczak \& Martowska, 2013).

Buhrmester et al. (1988) singled out five kinds of competences essential for coping in interpersonal situations: initiation of relations, assertive influence, self-revelation, emotional support, and conflict solving. The first two competences (initiation of relations and assertive influence) are related to the concept of assertiveness. The other three were classified as especially significant for deepening and sustaining interpersonal relations. One ought to note that the fact of acquiring interpersonal competences is not enough to be capable and effective at an interpersonal level. One must also possess knowledge allowing for analysis of social situations and behaving in ways appropriate for those situations. An equally important component is one's assumed interpersonal attitude towards others and oneself.

Psychologists focused on a traits-based approach to research into personality (e.g. Allport, Cattell, Eysenck) adopt a thesis proposing that personality as an organizing structure determines specific behaviours of the subject. Costa and McCrae, the creators of the five-factor model of personality, see the source of human behaviour in basic traits (conscientiousness, agreeableness, neuroticism, openness to experience, and extraversion). They are particular dispositions towards feeling and behaving in an appropriate way (John \& Robins, 2021). The above information allows one to assume that those basic dispositions may also influence levels of social competences. Such a conclusion derives from the way of understanding social competences as "complex skills influencing effective functioning in social situations, acquired in the process of social training" (Matczak, 2001, p. 7).

Research into interdependence of the five personality traits described in the Big Five model and the social competences reveals that interpersonal competences correlate negatively with neuroticism and positively with the other four traits: conscientiousness, agreeableness, openness to experience, and extraversion. It also transpires that in order to have a positive view of one's own interpersonal compe- 
tences it is important to be able to easily and earnestly establish close relations, openly express one's feelings, be active and lively in social relations, have a happy disposition, be optimistic and open (Klinkosz et al., 2017). For example, extroverts are sociable, but that is just one domain of extraversion. Apart from liking people, extroverts are also assertive, active, and talkative. They like excitement, stimulation and have a tendency toward a happy disposition. They are lively, energetic, and optimistic (Han \& Son, 2020).

Mayer et al. (2016) conducted research into the relationship between emotional intelligence and the five personality traits from Costa and McCrae's Big Five model and discovered the following relations: a weak positive correlation between emotional intelligence and openness $(\mathrm{O}, .18)$, conscientiousness $(\mathrm{C}, .15)$, extraversion (E, .12) and agreeableness (A, .25) and a weak negative correlation between emotional intelligence and neuroticism $(\mathrm{N},-.17)$. Initiation of interpersonal contact is helped by belief in other people's honesty and good intentions, sincerity and straightforwardness, generosity, kindness, readiness to help, ability to forgive and forget transgressions, self-confidence, being systematic, upholding of ethical standards and being organized. Ability to deliver negative messages towards others is helped by a high level of ambition and aspiration, hard-working attitude, and focus of achieving goals. Solving interpersonal conflicts is aided by traits such as: tenderness and sincerity, modesty, humbleness, kindness, and respect. A high propensity for stress, oversensitivity, lack of ability to control one's desires, exaggerated self-criticism, tendency to get easily discouraged, and experiencing emotions in a negative way greatly impede attempts to establish and maintain interpersonal contact (Klinkosz et al., 2017).

\section{INTERPERSONAL SKILLS IN UNIVERSITY STUDENTS}

University time is one of the most influential educational stages in one's life; it is a time of accumulation of changes related to a variety of dimensions of life. Young people, often away from their parents, learn how to be independent, make new friends, and make decisions related to their personal and professional life (Seal et al., 2015). Zimbardo et al. (2017) point out that being a university student alone belongs to the group of stressors or significantly difficult, serious challenges. What changes is not just how we learn, but also the expectations, the environment, social interactions and, as is the case with many young people, the existential and material sphere. Additional emotional experience is related to missing family and friends, who used to be physically close and we could count on their support. Efficient functioning in a new social environment requires activation of one's interpersonal competences and development of new interpersonal relations.

Research into effective leadership and collaborative work leads to the conclusion that interpersonal competences are one of the essential factors required to achieve common goals in various groups and society. Interpersonal competences, such as communication skills and ability to establish strong relations, make up the most important factors for achieving success in relations with others (Britton et al., 2017; Fought \& Misawa, 2016). Pupils and students who easily and effectively establish interpersonal relations are better able to cope with difficulties. They are able to accept support offered by others as well as ask for it when they are experiencing problems (Iskra, 2015; Iskra \& Klinkosz, 2020). An important adaptive function is also fulfilled by emotional intelligence, which is an indicator of effectiveness of coping with life's challenges (Mayer et al., 2016).

Ever since interpersonal competences became recognized as an important driving power behind achievements in the social dimension increasing attention has been paid to the development of those traits in students at all levels of education (McConnell, 2018). Schools and universities get engaged in preparations and promotion of courses focusing on interpersonal skills, because they think that employers of their students will be expected to have interpersonal competences in various work environments in the near future (Han \& Son, 2020; Ledzińska, 2017).

Learning processes of acquisition of social skills, and actively influencing their development through promotion of workshops and psychological training in that area may positively influence development of society, shaping responsible and mature people. Research in this area proves that influencing active development of youth's social skills has a wide impact on their development (McConnell, 2018). Social competence training leads to a higher degree of socialization. Moreover, development of those competences prevents occurrence of social pathologies amongst groups of pupils and students on campuses, halls of residence, sports halls, clubs, and discos. It also helps with adaptation of new pupils and students to an unknown environment at a new school or university, but it also eliminates or softens the effects of aggression in peer groups (McConnell, 2018; Prusiński, 2017; Suchodolska, 2017).

Interpersonal relations established by students in a new educational situation of university life are derived from their earlier social experiences and existing competences, and they can be based on domination, cooperation, or submissiveness. Wiggins (1995) claims that the interpersonal circumplex is the best structure for the visualization of interpersonal behaviour, because such behaviour influences every participant's feelings of pride (Status) and security (Support). Wiggins arranges interpersonal behaviour 
in a continuous fashion inside a circumplex in eight categories (octants). The concept of an interpersonal wheel conveniently describes interpersonal relations of university students based on the student's characteristic styles of introducing themselves and their chosen modes of communication (Sękowski \& Klinkosz, 2016).

Relations with others can help students meet certain needs such as acceptance, regard, closeness, community, compassion, love, understanding, respect, support, justice, and trust. Contact with another person may have different functions and different shape, e.g. expression of one's emotions, being exposed to others' emotions, being listened to, showing or receiving compassion, revealing feelings, presenting one's views or opinions, expressing needs, expressing expectations, asking for something, confronting others, receiving information about oneself, cooperation, playing, being someone important to others, seeking acceptance, sharing one's experiences, seeking and obtaining advice on solving problems, solving conflicts, learning new behaviours, introspection, receiving and offering support and help (Guzmán-Simón et al., 2017; Iskra \& Klinkosz, 2020).

\section{EMOTIONAL INTELLIGENCE IN UNIVERSITY STUDENTS}

The concept of emotional intelligence proposed by Salovey and Mayer (Mayer et al., 2016) has quickly gained popularity, within both the scientific community and the media (Knopp, 2005). Goleman's work (1995) has led to promotion of emotional intelligence, which has begun to be considered as one of the kinds of wisdom made up of self-awareness, awareness of one's feelings, using one's feelings in making life decisions, effective control of emotions and moods (fear, anger, depression), ability to motivate oneself, maintaining optimism despite misfortunes, empathy (ability to feel other people's feelings in a given situation), and ability to establish and maintain good relations with other people. It is therefore not surprising that in this context, the American Dialect Society recognised emotional intelligence as the most useful new term in 1995 (Carr, 2009).

The emotional intelligence model proposed by Salovey and Mayer (Mayer et al., 2016) assumes that emotional intelligence is related to the competences used to process information related to one's own and other people's emotions. Acquiring and shaping ability to control one's own emotions and to use emotions to build mutual understanding is the basis of solid functioning of people in relations with other people. Emotional intelligence encompasses four elementary competences: self-awareness, self-management, social awareness, and relationship management. Zimbardo and Gerrig (2012) maintain that two kinds of competences are the basis of effectively functioning in the social context. The first of those competences is "ability to adequately express emotions" (so that others can recognize them correctly). The second one is "ability to recognize other people's emotions", which helps understand emotions of others, predict their behaviour, and build correct interpersonal relations.

Thanks to the interest in emotional intelligence a lot of programs and courses have been developed, which aimed to increase emotional intelligence at different stages of people's development and education and as such allow them to take advantage of their own emotional reactions to build up their own identity and to cope with the challenges emerging in interpersonal relations (Mayer et al., 2016). As pointed out by Palmer et al. (2002), high levels of emotional intelligence contribute to the experience of social wellbeing and help cope with interpersonal problems. High levels of emotional intelligence are an important protection against negative effects of social stress experienced in new situations by young people (Fernández-Berrocal \& Extremera, 2016).

Young people possessing high emotional intelligence will function better, both in the academic environment and amongst their peers; they will be more open to their own and other people's emotions, be able to understand them better and recognize when someone needs help (Matczak \& Knopp, 2013; Prusiński, 2017; Suchodolska, 2017).

Research conducted thus far points toward relations between emotional intelligence and psychophysical wellbeing, self-esteem, life satisfaction, happiness, self-development, and professional success. In relation to students, such research focuses on the relationship between emotional intelligence and academic success, ability to cope with stress, wellbeing, and social competences (Monnier, 2015; PostigoZegarra et al., 2019).

One can therefore expect with high probability that interpersonal competences understood as "complex skills conditioning effectiveness of coping in specific kinds of situations, acquired during the course of social training" (Matczak, 2001, p. 7) ought to point out significant relations with emotional intelligence amongst subjects. Ability to reveal one's feelings, both positive and negative, awareness of the consequences of experiencing specific (strong) emotions, ability to understand, recognize, identify emotional states of other people and ability to calm down one's undesirable emotions in specific situations is the basis for establishing positive interpersonal relations (Klinkosz et al., 2017). As Matczak and Knopp (2013) write, the way of experiencing feelings, expressing them and coping with them influences one's interpersonal relations and social interactions.

The research problem formulated based on the presented theoretical analyses is concerned with 
co-dependence of interpersonal competences of students with the skills related to establishing contact with others (interpersonal relations) and emotional intelligence. Based on the theoretical assumptions, one can expect that interpersonal competences will positively correlate with interpersonal relations directed as cooperation, support, exhibiting initiative and mutual understanding, and with students' emotional intelligence (its various aspects).

\section{PARTICIPANTS AND PROCEDURE}

\section{PARTICIPANTS}

The participants in the study were 173 psychology students of three universities in Poland (92 women and 81 men). The mean age of these participants was 21.40 years $(S D=2.30)$. The participants were invited to voluntarily complete the Interpersonal Competence Questionnaire, the Interpersonal Adjective Scales, and the Popular Emotional Intelligence Questionnaire. Students went to a laboratory during their break time. They were briefed on the purpose and procedure of the current study by a researcher individually. They were also assured that their responses would be kept anonymous and confidential. Before entering the study, each participant gave oral consent to participate. Under the above conditions, written consent was not required.

\section{MATERIALS AND PROCEDURE}

The Interpersonal Competence Questionnaire (ICQ-R; Buhrmester et al., 1988; Polish adaptation by Klinkosz et al., 2017) is a method that allows self-description from the aspect of one's interpersonal competences (version A). This instrument is used to measure those competences that contribute to effective functioning in interpersonal relations, specifically in close relations based on friendship or love. Researchers obtained high internal correspondence coefficients for the Polish version of the ICQ-R questionnaire the values of Cronbach's $\alpha$ coefficient were between .84 and .92 (Klinkosz et al., 2017). A short description of the scales used in the ICQ-R questionnaire can be found below (Buhrmester et al., 1988).

Initiating relationships (IR) - measures ability to initiate interaction, with either a known or an unknown person. IR underscores the social interaction engagement aspect, the ability to create and modify behaviours, which helps one stay in social relations and increase effectiveness in acquiring friends. This aspect also points to social popularity and being liked by others. Having the skills necessary to initiate interpersonal contacts helps one adapt to existing social conditions and new situations.
Negative assertion (NA) - measures ability to confirm personal privileges and the ability to express dissatisfaction with other people interfering with one's personal matters. The NA scale should also be understood as the ability to declare personal matters; express dissatisfaction in an assertive fashion and critique other peoples' actions; self-confidence that expresses itself as an expression of wishes, positive and negative demands; and ability to state a decisive 'no.' This scale measures one's ability to take care of oneself but also one's effectiveness in realizing one's own needs and goals through influencing others or resisting external pressure.

Self-disclosure (SD) - allows the estimation of one's proclivity to reveal personal matters and also to disclose one's secrets. Argyle (1999) claims that competences related to self-disclosure are essential in difficult situations, such as intimate relations, in which one remains in a close interpersonal relation with one's partner. Self-disclosure conditions the ability to maintain appropriate, stable, and honest interpersonal relations as well as to develop relations through sharing personal information.

Providing emotional support (PES) - allows the estimation of the ability to emotionally support other, closely related people.

Conflict resolution (CR) - allows the estimation of the ability to cope with interpersonal conflict, which occurs in close relations. This scale allows one to judge one's ability to constructively resolve conflicts without fighting and blame. It is related to the measurement of adults' satisfaction with marriage (Gottman, 1979) and with teenagers' levels of "dating" success (Twentyman et al., 1981). This scale measures the ability to efficiently and effectively undertake interpersonal challenges and develop socially acceptable behaviour in conflict situations, which leads to the preservation of satisfactory contacts and interpersonal relations as well as of a positive social image.

The Interpersonal Adjective Scales (IAS; Wiggins, 1995; Polish adaptation by Sękowski \& Klinkosz, 2016 ) is a method for describing oneself based on two important dimensions of interpersonal transaction: domination and care. The IAS comprises 64 adjectives that describe interpersonal relations. The subject evaluates herself or himself on an 8-point Likert scale using estimations of how accurately (or inaccurately) each adjective defines them. Collected IAS results allow characterization of the subject using eight dimensions arranged on a circumplex, with domination and care on the main axes. Internal compatibility coefficients (Cronbach's $\alpha$ ) for Polish normalization samples, depending on the scale, fell within .77 and .90 (Sękowski \& Klinkosz, 2016). A short description of the scales is given below. Three elements have been included. The first one describes the characteristics of a particular type of behaviour, 
the second one concerns interpersonal problems, and the third refers to personality disorders.

Assured-dominant (PA): a) tendency towards taking the initiative in social situations, individualism; b) controlling others, manipulating; c) narcissistic personality.

Arrogant-calculating (BC): a) tendency towards humiliation and "exploitation" of others, competitiveness; b) vindictiveness; c) disregard for and violation of the rights vested in others.

Cold-hearted (DE): a) autonomy, freedom from social conventions; b) lack of feeling, inability to cooperate and forgive; c) paranoid personality.

Aloof-introverted (FG): a) aloofness and distance in social transactions; b) anxiousness and embarrassment in the presence of others; c) schizoid personality.

Unassured-submissive (HI): a) lack of assuredness, gentleness in contacts with others; b) lack of firmness and assertiveness towards others; c) avoidant personality (social inhibition, feeling of inadequacy).

Unassuming-ingenuous (JK): a) understanding and acceptance of others; b) gullibility, naiveté, allowance of exploitation; c) dependence, submissiveness, fears of rejection.

Warm-agreeable (LM): a) sympathy, caring for others; b) excessive generosity, permissiveness; c) welladjusted.

Gregarious-extraverted (NO): a) sociability, vivaciousness in social transactions; b) excessive self-disclosure, attracting attention; c) "histrionic" personality, excessive emotionality.

The Popular Emotional Intelligence Questionnaire (PKIE; Jaworowska et al., 2005) is based on the concept of emotional intelligence (Mayer et al., 2016). According to the researchers, emotional intelligence defines one's ability to process emotional information and use it to better understand the world and function within it. The PKIE presents 94 ways of describing oneself. The subjects describe themselves using a 5-point scale, based on their own estimation of how much they think each description matches them. The PKIE evaluates various cognitive skills, thanks to which human beings utilize their own emotions to solve problems. The questionnaire measures one's general level of emotional intelligence, as well as the level of emotional intelligence within four different aspects. The internal compatibility coefficient (Cronbach's $\alpha$ ) for the general result is equal to .80 and ranges between .74 and .88 for the four more specific scales. The following four paragraphs contain a short description of PKIE scales (Jaworowska et al., 2005):

Ability to accept, express, and use one's own emotions in action (A) - measures the subject's ability to express what they feel and manifest (positive emotions, such as admiration, love, and gratefulness versus negative emotions, such as fear, rage, indignation, and dislike).
Ability to empathise (E) - the EMP scale measures one's ability to recognize and understand other people's emotions, which helps understand other people's behaviour and correctly interpret their intentions, recognize what they are experiencing and differentiate between honest and dishonest expressions of feelings.

Ability to control (C) - assesses conscious control of one's emotions, ability to invoke certain emotions in oneself and to control their course (e.g., dampening of excessive agitation) as well as the ability to quiet unwanted emotions.

Ability to understand and recognize one's own emotions (U) - assesses one's ability to evaluate emotions experienced in a given moment; ability to name feelings and ability to differentiate between stronger and weaker emotions.

\section{RESULTS}

In this study, a group of 173 students was assessed with the ICQ-R, the IAS and the PKIE. Descriptive statistics (means, standards deviations, ranges for each of the measures of interpersonal competences, interpersonal relations, and emotional intelligence) are presented in Table 1 .

A series of correlation analyses was used to examine the relationships between interpersonal competences and interpersonal relations, and interpersonal competences and emotional intelligence as well.

Table 2 shows the correlation between the five domains of social competence (ICQ-R) and the eight interpersonal scales (IAS), and the four aspects of emotional intelligence (PKIE) (see Table 2). All analyses are based on the standardized results published in manuals (Klinkosz et al., 2017; Sękowski \& Klinkosz, 2016; Jaworowska et al., 2005).

We obtained 34 statistically significant correlations (of absolute value greater than .30) between the test scales used. The results obtained in this study are in line with expectations, as well as with the theoretical interpretation of the ICQ-R.

The students' ability to establish social contacts (IR) goes hand in hand with their feeling of self-confidence (PA, .66), good personal adaptation, tendency to take the initiative in social situations (LM, .34) and great openness towards others (NO, .70). Ability to establish relations is also helped by the ability to express what one feels at a given moment, both in terms of positive and negative emotions (A, .48). Detrimental factors are: too strong a tendency to compete; strong autonomy; inability to cooperate and forgive (DE, - .35), specifically, restraint in social situations; "keeping others at a distance" (FG, -.63); and lack of decisiveness and assertiveness towards others (HI, -.54).

The students' ability to take care of themselves and express dissatisfaction in a firm and assertive 
Table 1

Descriptive statistics for measures of interpersonal competences, interpersonal relations, and emotional intelligence

\begin{tabular}{|c|c|c|c|}
\hline & $M$ & $S D$ & Range \\
\hline \multicolumn{4}{|l|}{ ICQ-R } \\
\hline Initiating relationships (IR) & 26.35 & 6.71 & $8-38$ \\
\hline Negative assertion (NA) & 31.14 & 4.10 & $19-40$ \\
\hline Self-disclosure (SD) & 28.92 & 4.87 & $15-39$ \\
\hline Providing emotional support (PES) & 24.66 & 5.71 & $9-37$ \\
\hline Conflict resolution (CR) & 27.54 & 4.33 & 13-39 \\
\hline \multicolumn{4}{|l|}{ IAS } \\
\hline Assured-dominant (PA) & 4.67 & 1.33 & $2-7$ \\
\hline Arrogant-calculating (BC) & 2.32 & 1.08 & $1-6$ \\
\hline Cold-hearted (DE) & 1.93 & 1.03 & $1-6$ \\
\hline Aloof-introverted (FG) & 3.39 & 1.40 & $1-7$ \\
\hline Unassured-submissive (HI) & 4.40 & 1.25 & $1-7$ \\
\hline Unassuming-ingenuous (JK) & 5.72 & 1.03 & $3-8$ \\
\hline Warm-agreeable (LM) & 6.35 & 1.03 & $4-8$ \\
\hline Gregarious-extraverted (NO) & 5.72 & 1.07 & $3-8$ \\
\hline \multicolumn{4}{|l|}{ PKIE } \\
\hline Ability to accept (A) & 52.82 & 8.50 & $30-75$ \\
\hline Ability to empathise (E) & 70.41 & 7.64 & $46-90$ \\
\hline Ability to control (C) & 31.73 & 6.70 & $16-50$ \\
\hline Understand (U) & 30.99 & 6.62 & $15-49$ \\
\hline
\end{tabular}

Note. $N=173$. ICQ-R - the Interpersonal Competence Questionnaire; IAS - the Interpersonal Adjective Scales; PKIE - the Popular Emotional Intelligence Questionnaire.

way (NA), has a positive association with students' individualism and their tendency to take the initiative in social situations (PA, .41). This ability is also connected with the ability to "come forward" with kindness and warmth in interpersonal contacts (LM, .42), as well as with students seeking situations that would allow them to form harmonious friendship relationships (NO, .47). An important role is also played by the ability to express both the positive and the negative emotional aspects of what the person is feeling in a given situation (A, .33), as well as the ability to recognize other people's emotions (E, .56). The negative correlation noted in the results of the three IAS scales shows that students' assertive influence on others is connected to the ability to cooperate and to support others in social situations (DE, -.46) and to their ease of establishing relations with others (FG, -.45), lack of fear in social situations, good adaptation to the environment and high self-confidence (HI, -.33).

Students' tendency to reveal their own secrets and intimate information about themselves (SD) points to positive correlations with their domination, assertiveness and courage in social situations (PA, .60) and their kindness and care for others $(\mathrm{NO}, .50)$. Being open in communication in personal experiences and maintaining close interpersonal relations is not helped by emotional distance, the lack of support for one's partner in difficult situations (DE, -.37), the tendency to reject others' friendly gestures (FG, -.50$)$, or the fear of establishing new contacts (HI, -.49).

The ability to emotionally support others (PES) positively correlates with domination in interpersonal relations and courageous decision making (PA, .38). Students readily take part in situations where they may establish social relations and friendships (NO, .40). An important role is also played by the ability to express both the positive and negative emotional aspects of what one is feeling in a given situation (A, .51) and by one's ability to recognize other people's emotions, which allows one to understand their behaviour, recognize intent and evaluate sincerity of their actions (E, .56). The ability to offer 
Table 2

Correlation between interpersonal competences, interpersonal relations, and emotional intelligence

\begin{tabular}{|c|c|c|c|c|c|}
\hline & \multicolumn{5}{|c|}{ ICQ-R } \\
\hline & $\begin{array}{l}\text { Initiating } \\
\text { relationships } \\
\text { (IR) }\end{array}$ & $\begin{array}{c}\text { Negative } \\
\text { assertion } \\
\quad(\mathrm{NA})\end{array}$ & $\begin{array}{c}\text { Self- } \\
\text { disclosure } \\
\text { (SD) }\end{array}$ & $\begin{array}{c}\text { Providing } \\
\text { emotional } \\
\text { support } \\
\text { (PES) }\end{array}$ & $\begin{array}{l}\text { Conflict } \\
\text { resolution } \\
(\mathrm{CR})\end{array}$ \\
\hline \multicolumn{6}{|l|}{ IAS } \\
\hline Assured-dominant (PA) & $.66^{* *}$ & $.41^{* *}$ & $.60^{* *}$ & $.38^{* *}$ & $.42^{* *}$ \\
\hline \multicolumn{6}{|l|}{ Arrogant-calculating (BC) } \\
\hline Cold-hearted (DE) & $-.35^{* *}$ & $-.46^{* *}$ & $-.37^{* *}$ & $-.41^{* *}$ & $-.37^{* *}$ \\
\hline Aloof-introverted (FG) & $-.63^{* *}$ & $-.45^{* *}$ & $-.50^{* *}$ & $-.44^{* *}$ & $-.33^{* *}$ \\
\hline Unassured-submissive $(\mathrm{HI})$ & $-.54^{* *}$ & $-.33^{* *}$ & $-.49^{* *}$ & $-.34^{* *}$ & \\
\hline \multicolumn{6}{|l|}{ Unassuming-ingenuous (JK) } \\
\hline Warm-agreeable (LM) & $.34^{* *}$ & $.42^{* *}$ & $.35^{* *}$ & & $.51^{* *}$ \\
\hline Gregarious-extraverted (NO) & $.70^{* *}$ & $.47^{* *}$ & $.50^{* *}$ & $.40^{* *}$ & $.53^{* *}$ \\
\hline \multicolumn{6}{|l|}{ PKIE } \\
\hline Ability to accept (A) & $.48^{* *}$ & $.33^{* *}$ & & $.51^{*}$ & \\
\hline Ability to empathise (E) & & $.56^{* *}$ & & $.36^{*}$ & $.43^{* *}$ \\
\hline \multicolumn{6}{|l|}{ Ability to control (C) } \\
\hline Ability to understand (U) & & & & & \\
\hline
\end{tabular}

emotional support to others (PES) is not helped by maintaining distance in a relationship, independence, not caring for social norms (DE, -.41), a tendency to avoid social contact (FG, -.44), or fear of initiating contact, withdrawal from social meetings and lower self-esteem (HI, -.34).

In regard to solving conflict, especially in close relations, students are helped by their dominance over others. That skill allows them to lead others, take the initiative and make decisions in conflictual situations (PA, .42). Defusing tensions in interpersonal relations is helped by a kind attitude, kindness, and care but also by the ability to forgive and show compassion (LM, .51). Solving interpersonal conflicts is helped by extroversion, which allows oneself to regard oneself as a social and happy person (NO, .53). An important role is also played by the ability to recognize other people's emotions, which helps one understand their behaviour, recognize intent and evaluate the sincerity of their actions (E, .43). Students' ability to solve interpersonal conflicts is hampered by the lack of ability to cooperate and support those in need, egoism and high independence (DE, -.37). Dissipating social tension is not helped by students' isolation, restraint, and antisocial behaviour (FG, -.33).

\section{DISCUSSION}

The conducted research allowed the authors to confirm the existence of a relationship between interpersonal competences and the types of interpersonal contact and emotional intelligence. Students' ability to function in optimal ways in social relations forms the basis for positive experiences and conditions for academic success. Interpersonal competences that influence relations with other people help students establish relationships, friendships and contacts with their peers as well as with their lecturers.

In order to achieve academic success and high professional status, find friends, and be happy in marriage or a partnership as well as family life, we need to be able to direct our emotions, to the awareness thereof. Emotional intelligence allows us not only to better understand our own experience, but also constitutes a certain kind of wisdom allowing us to understand other people's behaviour, recognize 
their emotions, correctly recognize their intentions, and recognize the sincerity of the expression of their feelings. Emotional intelligence makes it easier for us to exist within interpersonal relationships related to both our private and professional lives and to cope with the conflicts and the hardships of everyday life (Monnier, 2015). Many students describe their time at university, especially the first few months, as a struggle with many hardships. The problems experienced by the students have their origin in the lack of ability to function in social situations, specifically in the lack of ability to develop interpersonal relations and to understand oneself and others.

Research conducted by Iskra (2015) points out that many students experiencing difficulties cannot cope with them. This originates from the lack of ability to find their footing in new relations and to find a way to cope with the demands that these present. Students experience difficulties in relations with others when they move, reduce contacts with their old friends and avoid entering into new relations, in which they do not feel safe and sure.

The knowledge obtained as the result of the presented research and analysis is a starting point for actions leading to the development of practical methods related to social training of youth entering university designed to shape and expand their ability to enter into mature interpersonal relations that will become a source of support in difficult situations. In this context, it is important to recognize the role of academic teachers and their ability to establish relations with students based on openness, mutual respect, ability to listen, provide support and motivate intellectual curiosity and self-improvement.

\section{CONCLUSIONS}

The consequence of the research conducted so far is the authors' work on the Students' Difficulties Questionnaire, which will be used to diagnose the kind and the level of difficulties experienced by the students in three areas: emotional reactions, social alienation, and requirement overload. In the next stage of development, the results obtained from students experiencing emotional difficulties will form the basis for the introduction of training aimed at the development of interpersonal competences and emotional intelligence. An effective form of help for students with difficulties is not limited to provision of support by academic staff and students supporting each other, but it is mainly based on organized group training encompassing social competences and students meeting tutors, which helps students get to know new people better, overcome difficulties, and adapt to the academic environment, providing them with the best possible preparedness for social functioning and achieving academic success (Youde, 2016).

\section{RefERENCES}

Argyle, M. (1999). Causes and correlate of happiness. In D. Kahneman, E. Diener, \& Schwarz, N. (Eds.), Well-being: The foundations of hedonic psychology (pp. 353-373). Russell Sage Foundation.

Britton, E., Simper, N., Leger, A., \& Stephenson, J. (2017). Assessing teamwork in undergraduate education: a measurement tool to evaluate individual teamwork skills. Assessment \& Evaluation in Higher Education, 42, 378-397. https://doi.org/ 10.1080/02602938.2015.1116497

Buhrmester, D., Furman, W., Wittenberg, M. T., \& Reis, H. T. (1988). Five domains of interpersonal competence in peer relationships. Journal of Personality and Social Psychology, 55, 991-1008. https://doi.org/10.1037//0022-3514.55.6.991

Cabero-Almenara, J., \& Marín-Díaz, V. (2018). Blended learning and augmented reality: Experiences of educational design. RIED. Revista Iberoamericana de Educación a Distancia, 21, 57-74. https://doi. org/10.5944/ried.21.1.18719

Carr, A. (2009). Psychologia pozytywna. Nauka o szcześciu i ludzkich sitach [Positive psychology. The science of happiness and human strengths]. Wydawnictwo Zysk i S-ka.

DeLamater, J., \& Ward, A. (2014) (Eds.). Handbook of social psychology (6th edition). Springer.

Fernández-Berrocal, P., \& Extremera, N. (2016). Ability emotional intelligence, depression, and wellbeing. Emotion Review, 8, 311-315. https://doi.org/ $10.1177 / 1754073916650494$

Fought, R. L., \& Misawa, M. (2016). Effective leadership in academic health sciences libraries: a qualitative phenomenological study. Journal of Library Administration, 56, 974-989. https://doi.org/10.108 0/01930826.2015.1130548

Goleman, D. (1995). Emotional intelligence. Bantam Books, Inc.

Gottman, J. M. (1979). Marital interaction: Experimental investigations. Academic Press.

Guzmán-Simón, F., García-Jiménez, E., \& LópezCobo, I. (2017). Undergraduate students' perspectives on digital competence and academic literacy in a Spanish University. Computers in Human Behavior, 74, 196-204. https://doi.org/10.1016/j.chb. 2017.04.040

Han, S. L., \& Son, H. S. (2020). Effects on cooperative learning on the improvement of interpersonal competence among students in classroom environments. International Online Journal of Education and Teaching, 7, 17-28.

Iskra, J. (2015). Sposoby radzenia sobie z trudnościami przez studentów [Coping with difficulties by students]. Difin.

Iskra, J., \& Klinkosz, W. (2020). Trudności doświadczane przez studentów [Difficulties experienced by students]. Difin. 
Jaworowska, A., Matczak, A., Ciechanowicz, A., Stańczak, J., \& Zalewska, E. (2005). Popularny Kwestionariusz Inteligencji Emocjonalnej: PKIE. Podręcznik [The Popular Emotional Intelligence Questionnaire. Professional manual]. Pracownia Testów Psychologicznych PTP.

John, O. P., \& Robins, R. W. (2021) (Eds.). Handbook of personality: Theory and research. Guilford Press.

Klinkosz, W., Iskra, J., \& Dawidowicz, M. (2017). Kwestionariusz Kompetencji Interpersonalnych ICQ-R. Podręcznik [The Interpersonal Competence Questionnaire ICQ-R. Professional manual]. Pracownia Testów Psychologicznych i Pedagogicznych.

Knopp, K. (2005). Rola inteligencji emocjonalnej w życiu człowieka [The role of emotional intelligence in human life]. Studia Psychologica, 6, 221-236.

Ledzińska, M. (2017). Nauczyciela akademickiego spojrzenie na rozwój w dobie przemian ogólnoświatowych [An academic teacher's perspective on development in the era of global changes]. Psychologia Rozwojowa, 22, 9-25. https://doi.org/10. 4467/20843879PR.17.001.6415

Matczak, A. (2001). Kwestionariusz Kompetencji Społecznych. Podręcznik [The Social Competence Questionnaire. Professional manual]. Pracownia Testów Psychologicznych PTP.

Matczak, A., \& Knopp, K. A. (2013). Znaczenie inteligencji emocjonalnej w funkcjonowaniu człowieka [The importance of emotional intelligence in human functioning]. Wydawnictwo Liberi Libri.

Matczak, A., \& Martowska, K. (2013). Profil Kompetencji Spotecznych: PROKOS. Podręcznik [Profile of Social Competences: PROKOS. Manual]. Pracownia Testów Psychologicznych PTP.

Mayer, J. D., Salovey, P., \& Caruso, D. (2016). The ability model of emotional intelligence: Principles and updates. Emotion Review, 2, 363-370. https:// doi.org/10.1177/1754073916639667

McConnell, C. R. (2018). Interpersonal competence in the management of people. The Health Care Manager, 37, 358-367. https://doi.org/10.1097/HCM. 0000000000000237

Monnier, M. (2015). Difficulties in defining socialemotional intelligence, competences and skills - a theoretical analysis and structural suggestion. International Journal for Research in Vocational Education and Training, 2, 59-84. https://doi. org/10:13152/IJRVET.2.1.4

Palmer, B., Donaldson, C., \& Stough, C. (2002). Emotional intelligence and life satisfaction. Personality and Individual Differences, 33, 1091-1100. https:// doi.org/10.1016/S0191-8869(01)00215-X

Postigo-Zegarra, S., Schoeps, K., Montoya-Castilla, I., \& Escartí, A. (2019). Emotional education program for adolescents (PREDEMA): Evaluation from the perspective of students and effects on socio-affective competences. Journal for the Study of Educa- tion and Development, 42, 303-336. https://doi.org /10.1080/02103702.2019.1578925

Prusiński, T. (2017). Z badań nad przyjaźnią. Kompetencje społeczne a jakość relacji przyjacielskich [From research on friendship. Social competences and the quality of friendly relations]. Studia Psychologica: Theoria et Praxis, 1, 23-46. https://doi. org/10.21697/sp.2017.17.1.02

Seal, C. R., Miguel, K., Abdulaziz, A., Naumann, S. E., Royce-Davis, J., \& Drost, D. (2015). Personal-interpersonal competence assessment: a self-report instrument for student development. Research in Higher Education Journal, 27, 1-10.

Sękowski, A. E., \& Klinkosz, W. (2016). Interpersonalne Skale Przymiotnikowe IAS Jerry'ego S. Wigginsa. Podręcznik [The Interpersonal Adjective Scales IAS by Jerry S. Wiggins. Professional manual]. Pracownia Testów Psychologicznych PTP.

Smółka, P. (2016). Kompetencje społeczne. Metody pomiaru i doskonalenia umiejętności interpersonalnych [Social competence. Methods for measuring and improving interpersonal skills]. Wolters Kluwer.

Suchodolska, J. (2017). Poczucie jakości życia mtodych dorostych na przykładzie studenckiej społeczności akademickiej [The sense of the quality of life of young adults on the example of the student academic community]. Wydawnictwo Adam Marszałek.

Twentyman, C. T., Boland, T., \& McFall, R. M. (1981). Heterosocial avoidance in college males: Four studies. Behavior Modification, 5, 523-552. https:// doi.org/10.1177/014544558154005

Wiggins, J. S. (1995). Interpersonal Adjective Scales IAS. Professional manual. Psychological Assessment Resources, Inc.

Youde, A. (2016). Tutor emotional competences valued by learners in a blended learning context. European Journal of Open, Distance and e-Learning, 19, 81-97.

Zimbardo, P. G., \& Gerrig, R. J. (2012). Psychologia i życie [Psychology and life]. Wydawnictwo Naukowe PWN.

Zimbardo, P. G., Johnson, R. L., \& McCann, V. (2017). Psychology: Core concepts. Pearson Higher Education. 